\title{
Pendidikan Karakter Berbasis Nilai
}

\author{
Lian G. Otaya
}

Istitut Agama Islam Negeri Sultan Amai Gorontalo

Email: lian.otaya@yahoo.com

\begin{abstract}
Internalization of values-based character education on student himself can be done through an objective and transparent assessment system. This will be useful to foster honesty, discipline, and responsibility of students. Objective assessment was actually born of conscience. The real truth in it as something that is produced by conscience is something that is pure and candid. Transparent assessment of the implementation of the assessment should be known, from the aspect of the values obtained, the basic decision-making, processing until the final result indicated value, and acceptable. With such a rating system that would give birth to a student who has a character to help form a strong mental. Strong mental is precondition to be qualified competitive human.
\end{abstract}

Keywords: character, internalization, evaluation, mental

\begin{abstract}
Abstrak
Internalisasi pendidikan karakter berbasis nilai pada diri mahasiswa dapat dilakukan melalui sistem penilaian yang objektif dan transparan. Hal ini akan berguna untuk memupuk kejujuran, kedisiplinan, dan tanggung jawab pada diri mahasiswa. Penilaian yang objektif itu sebetulnya terlahir dari hati nurani. Kebenaran sejati ada di dalamnya karena sesuatu yang dihasilkan oleh hati nurani merupakan sesuatu yang murni dan apa adanya. Penilaian yang transparan harus diketahui pelaksanaan penilaiannya, dari aspek nilai yang didapat, dasar pengambilan keputusan, pengolahan nilai sampai hasil akhirnya tertera, dan dapat diterima. Dengan sistem penilaian yang demikian akan melahirkan mahasiswa yang memiliki karakter dalam membantu pembentukan mental yang kuat. Mental yang kuat merupakan prasyarat untuk menjadi manusia yang berkualitas dan kompetitif.
\end{abstract}

Kunci kunci: karakter, internalisasi, penilaian, mental. 


\section{A. Pendahuluan}

Penilaian merupakan salah satu bagian yang penting dalam kegiatan pembelajaran yang dilakukan oleh dosen sebagai evaluator pembelajaran. Dikatakan penting, karena kegiatan ini akan mencerminkan perkembangan dan kemajuan belajar mahasiswa dari waktu ke waktu. Selain itu, penilaian akan dapat memberikan gambaran kepada dosen mengenai pencapaian hasil belajar mahasiswanya.

Penilaian berguna untuk melihat keberhasilan suatu proses pembelajaran yang telah dijalankan. Apakah strategi dan metode yang telah dipilih dan digunakan saat proses perkuliahan sudah tepat atau belum? Apakah instrumen yang telah disusun dan dilaksanakan sudah memenuhi kriteria atau belum? Misalnya, dalam pembelajaran mata kuliah Statistika Pendidikan, penilaian memerlukan serangkaian proses dan prosedur sehingga lahirlah nilai terhadap masing-masing mahasiswa. Dengan sistem penilaian yang efektif akan menggambarkan kemajuan belajar mahasiswa yang tepat. Mahasiswa yang rajin belajar akan meraih hasil belajar yang optimal. Sebaliknya, mahasiswa yang malas belajar akan memperoleh hasil yang kurang memuaskan.

Namun kenyataan, yang terjadi saat ini tidak dapat dipungkiri bahwa dalam sistem penilaian hasil belajar mahasiswa sering menuai permasalahan. Kadangkala, mahasiswa menerima Kartu Hasil Studi (KHS) dengan nilai bagus, meskipun mahasiswa tersebut agak malas belajar atau jarang mengikuti proses perkuliahan. Bahkan bisa saja mahasiswa tidak mengikuti ujian akhir semester misalnya, namun nilainya tetap lengkap pada KHS. Terkadang mahasiswa merasa nilai yang didapatkan tidak sesuai dengan hasil belajarnya. Jika mahasiswa mendapatkan nilai yang tidak sesuai dari dosen, mereka takut untuk mempertanyakannya langsung kepada dosen mata kuliah bersangkutan. Biasanya permasalahan sering terjadi pada mahasiswa yang dikenal oleh dosen, atau memiliki kedekatan emosional dengan dosen nilainya pasti bagus. Padahal, proses penilaian mahasiswa sudah diatur mekanismenya mulai penilaian tugas individu, tugas kelompok, ujian tengah semester, ujian akhir semester dan partisipasinya, masing-masing sudah memakai formula tertentu sehingga menghasilkan nilai akhir yang tertera pada KHS.

Berbagai permasalahan di atas, diakibatkan oleh sistem penilaian dilakukan tidak berdasarkan pada prinsip penilaian. Padahal, sistem penilaian yang diterapkan oleh dosen dalam proses 
perkuliahan dapat menentukan keberhasilan mahasiswa selama mengikuti perkuliahan. Sistem penilaian yang baik, tentunya dilakukan berdasarkan prinsip-prinsip penilaian yang diatur dalam Permendikbud No. 66 Tahun 2013, bahwa standar penilaian pendidikan adalah kriteria mengenai mekanisme, prosedur, dan instrumen penilaian hasil belajar peserta didik di antaranya dengan menerapkan prinsip penilaian yang objektif dan transparan.

Untuk melakukan penilaian yang objektif, haruslah didasarkan pada data yang ada tentang kemajuan belajar mahasiswa, karena hasil penilaian harus menggambarkan keadaan mahasiswa sebenarnya, sesuai dengan kemampuan yang dimiliki. Penilaian didasarkan pada prosedur dan kriteria yang jelas tanpa dipengaruhi oleh subjektivitas, perbedaan latar belakang, agama, sosial-ekonomi, budaya, bahasa, gender, dan hubungan emosional. Sementara itu, untuk melakukan penilaian yang transparan, hendaknya harus dilakukan secara jujur agar mudah dipahami, sehingga hasilnya dapat ditindaklanjuti dan diketahui oleh pihak-pihak yang terkait. Demikian halnya, dalam menginternalisasi pendidikan karakter mahasiswa berbasis nilai dalam pembelajaran, dapat dilakukan melalui sistem penilaian yang objektif dan transparan untuk memupuk sikap jujur, disiplin, dan tanggung jawab mahasiswa.

\section{B. Pendidikan Karakter dan Landasan Filosofisnya}

Pendidikan karakter merupakan gabungan dari dua kata, yaitu pendidikan dan karakter. Kita ketahui, bahwa pengertian pendidikan begitu banyak versi yang menyebutkan. Salah satunya adalah Undang-Undang Nomor 20 Tahun 2003 tentang Sistem Pendidikan Nasional, disebutkan bahwa pendidikan adalah usaha sadar dan terencana untuk mewujudkan suasana belajar dan proses pembelajaran agar peserta didik secara aktif mengembangkan potensi dirinya untuk memiliki kekuatan keagamaan, pengendalian diri, kepribadian, kecerdasan, akhlak mulia, serta keterampilan yang diperlukan dirinya, masyarakat, bangsa, dan negara.

Sedangkan istilah karakter secara harfiah berasal dari Bahasa Latin kharakter, kharessian, dan xharaz, yang berarti tool for marking, kemudian dalam bahasa Inggris menjadi character yang berarti tabiat, budi pekerti dan watak. Dalam bahasa Arab, karakter diartikan "khuluq, sajīyah, țab'u" (budi pekerti, tabiat atau watak). Kadang juga diartikan syakhșiyyah yang artinya lebih dekat dengan 
personality (kepribadian). ${ }^{1}$ Sementara dari bahasa Yunani, karakter diistilahkan dengan "to mark" yang berarti menandai dan memfokuskan bagaimana mengaplikasikan nilai kebaikan dalam bentuk tindakan atau tingkah laku. Karakter berasal dari bahasa latin yang berarti "dipahat". Secara harfiah, karakter artinya adalah kualitas mental atau moral, kekuatan moral. ${ }^{2}$

Karakter mengacu pada serangkaian sikap (attitudes), perilaku (behaviors), motivasi (motivations), dan keterampilan (skill). Karakter mulia berarti individu memiliki pengetahuan tentang potensi dirinya yang ditandai dengan nilai-nilai seperti: reflektif, percaya diri, rasional, kritis, analitis, kreatif dan inovatif, mandiri, hidup sehat, bertanggung jawab, cinta ilmu, sabar, berhati-hati, rela berkorban, pemberani, ramah, setia, bekerja keras, tekun, ulet, gigih, teliti, berpikir positif, disiplin, antisipatif, inisiatif, visioner, bersahaja, semangat, dinamis, efisien, menghargai waktu, dedikatif, pengendalian diri, produktif, cinta keindahan (estetis), tabah, terbuka, dan tertib. Individu juga memiliki kesadaran untuk berbuat yang terbaik atau unggul, dan mampu bertindak sesuai potensi serta kesadarannya tersebut. Karakteristik adalah realisasi perkembangan positif sebagai individu (intelektual, emosional, sosial, etika, dan perilaku). ${ }^{3}$

Karakter diasosiasikan dengan temperamen yang memberinya sebuah definisi yang menekankan unsur psikososial yang dikaitkan dengan pendidikan dan lingkungan. Karakter juga dipahami dari sudut pandang behavioral yang menekankan unsur psikis yang dimiliki oleh individu sejak lahir. ${ }^{4}$ Dari pengertian ini karakter dianggap sama dengan kepribadian. Kepribadian dianggap sebagai ciri karakteristik, gaya, atau sifat khas seseorang, yang bersumber dari bentuk-bentuk yang diterima dari lingkungan. Misalnya pengaruh keluarga pada masa kecil dan bawaan seseorang sejak lahir.

${ }^{1}$ Zaenul Fitri Agus, Pendidikan Karakter Berbasis Nilai \& Etika di Sekolah, (Yogyakarta: Ar-Ruzz Media, 2012), hlm.20.

${ }^{2}$ Asmani Jamal Ma'mur, Tips Aplikasi Manajemen Sekolah, (Yogyakarta: DIVA Press, 2011), hlm.27-28.

${ }^{3}$ Aqib Zainal \& Sujak, Panduan dan Aplikasi Pendidikan Karakter untuk SD/MI, SMP/MTs,SMA/MA, SMK/MAK, (Bandung: Yrama Widya, 2012), hlm.2.

${ }^{4}$ Doni Koesoemo Albertus, Pendidikan Karakter: Strategi Mendidik Anak di Zaman Global, (Jakarta: Grasindo, 2010), hlm.78-79. 
Dari berbagai pendapat di atas, dapat dikatakan bahwa karakter adalah sifat kejiwaan, akhlak, atau budi pekerti yang menjadi ciri khas seseorang atau sekelompok orang. Karakter bukan barang jadi, tetapi dibentuk melalui proses pendidikan yang diajarkan secara serius, sungguh-sungguh, konsisten dan kreatif yang dimulai dari unit terkecil dalam keluarga, kemudian masyarakat, dan lembaga pendidikan secara umum. Dengan demikian dapat disimpulkan bahwa keberhasilan pendidikan karakter ditentukan oleh konsistensi perilaku seseorang yang sesuai dengan apa yang diucapkan, harus disadari atas ilmu dan pengetahuan dari sumber-sumber yang dapat dipertanggungjawabkan.

Berdasarkan tujuan pendidikan nasional, maka pendidikan karakter adalah suatu program pendidikan yang mengorganisasikan dan menyederhanakan sumber-sumber moral dan disajikan dengan memperhatikan pertimbangan psikologis untuk pertimbangan pendidikan. Dalam konteks pendidikan, pendidikan karakter adalah usaha sadar yang dilakukan untuk membentuk peserta didik menjadi pribadi positif, berakhlak karimah sesuai dengan standar kompetensi lulusan (SKL) sehingga dapat diimplementasikan dalam kehidupan sehari-hari.

Pendidikan karakter mengajarkan kebiasaan cara berpikir dan perilaku yang membantu individu untuk hidup dan bekerja bersama sebagai keluarga, masyarakat, dan bernegara dan membantu mereka untuk membuat keputusan yang dapat dipertanggungjawabkan. Dengan kata lain, pendidikan karakter mengajarkan anak didik berpikir cerdas, mengaktivasi otak tengah secara alami. ${ }^{5}$

Secara substantif, tujuan pendidikan karakter adalah membimbing dan memfasilitasi peserta didik agar memiliki karakter positif (baik). tujuan pendidikan karakter antara lain sebagai berikut: 1) mengembangkan potensi kalbu/nurani/afektif peserta didik sebagai manusia dan warga negara yang memiliki nilai-nilai budaya dan karakter bangsa, 2) mengembangkan kebiasaan dan perilaku peserta didik yang terpuji dan sejalan dengan nilai-nilai universal dan tradisi budaya bangsa yang religius, 3) menanamkan jiwa kepemimpinan dan tanggung jawab peserta didik sebagai generasi penerus bangsa,4) mengembangkan kemampuan peserta didik untuk menjadi manusia yang mandiri, kreatif, dan

${ }^{5}$ Khan Yahya, Pendidikan Karakter Berbasis Potensi Diri (Mendongkrak Kualitas Pendidikan), (Yogyakarta: Pelangi Publishing, 2010), hlm.1. 
berwawasan kebangsaan, 5) mengembangkan lingkungan kehidupan sekolah sebagai lingkungan belajar yang aman, jujur, penuh kreativitas serta dengan rasa kebangsaan yang tinggi dan penuh kekuatan (dignity). ${ }^{6}$

Dari berbagai penjelasan di atas, dapat dipahami bahwa tujuan pendidikan karakter adalah membentuk, menanamkan, memfasilitasi, mengembangkan nilai-nilai positif pada peserta didik sehingga menjadi pribadi yang unggul dan bermartabat.

Setiap paradigma pendidikan tidak bisa lepas dari akar filosofisnya. Demikian halnya dengan pendidikan karakter, karena pendidikan sebagai ilmu merupakan cabang dari filsafat dalam aplikasinya. Filsafat telah dihubungkan dengan kebijaksanaan praktis dan teoretis "memahami segala sesuatu secara filosofis". Socrates memiliki doktrin yang menyatakan bahwa, jika mengetahui apakah kebaikan itu?maka kita harus mengerjakannya. Namun doktrin ini benar hanya jika kita memasukkan realisasi dari apa yang kita ketahui secara teoretis dengan semangat emosional yang tepat ke dalam makna istilah "tahu".

Terkait filsafat pendidikan ada beberapa aliran yang saling merekonstruksi terhadap masing-masing paradigma pendidikan tersebut. Aliran-aliran filsafat tersebut kemudian membentuk paradigma yang berbeda-beda. Paradigma yang dimaksud adalah sebagai salah satu perspektif filosofis dalam membaca persoalan pendidikan. Dalam filsafat kontemporer terdapat beberapa jenis aliran filsafat diantaranya: aliran progresivisme, esensialisme, perenialisme, eksistensialisme, dan rekonstruksialisme. ${ }^{8}$

Aliran progresivisme memiliki ciri utama yaitu memberi kebebasan penuh terhadap manusia untuk menentukan hidupnya. Hal ini didasari kepercayaaan bahwa manusia memiliki kemampuan atau dengan kata lain potensi-potensi alamiah yang dapat digunakan untuk menyelesaikan masalah-masalah hidupnya (problem solving) yang bersifat menekan atau mengancam adanya

${ }^{6}$ Kemendiknas, Pengembangan Pendidikan Budaya dan Karakter Bangsa, (Jakarta: Badan Penelitian dan Pengembangan Pusat Kurikulum dan Perbukuan, 2010), hlm.7.

${ }^{7}$ Ewing AC, Persoalan-Persoalan Mendasar Filsafat, (Yogyakarta: Pustaka Pelajar, 2008), hlm.26.

${ }^{8}$ Rahman Putri, Pendidikan Karakter, (http://calongurukimia.blogspot.com/2012/06/ pendidikan-karakter.html. Diakses: 15 Mei 2013), hlm.3. 
manusia itu sendiri. Oleh karena itu, manusia harus dapat memfungsikan jiwanya untuk membina hidup yang penuh dengan rintangan. Lingkungan dan pengalaman menjadi hal yang penting dalam aliran ini. Masalah atau problem yang dihadapi manusia biasanya berasal dari lingkungan dan pengalaman-pengalaman yang dialaminya pada lingkungan di mana dia berada, manusia menjadi semakin mudah dan bijak dalam menyelesaikan problem hidup. Semakin sering manusia menghadapi tuntutan lingkungan, maka semakin matang persiapan seseorang dalam menghadapi tantangan atau tuntutan masa depan karena semakin banyak pengalaman yang didapat.

Filsafat Progresivisme merupakan aliran yang anti kemapanan sehingga bertentangan dengan Esensialisme. Maksudnya, Progresivisme berpandangan berpikir kearah depan (adanya kemajuan), secara terus-menerus merekonstruksi pengetahuan-pengetahuan menuju sebuah kesempurnaan. Dalam perspektif Progresivisme, pendidikan memberikan pengetahuan, melatih kemampuan berpikir (aspek kognitif). Manusia memiliki kedudukan yang lebih tinggi dibanding makhluk lain, yaitu dianugerahi akal dan kecerdasan. Sehingga dengan akal dan kecerdasan manusia diharapkan atau seseorang dapat mengetahui, memahami, dan mengembangkan potensi-potensi yang telah ada pada dirinya sejak dilahirkan. Akal membuat seseorang bersifat kreatif dan dinamis sebagai bekal dalam menghadapi dan menyelesaikan problem yang dihadapi sekarang maupun masa depan.

Aliran inilah yang menjadi dasar atau landasan terbentuknya pendidikan karakter. Pandangan yang mengatakan bahwa manusia memiliki potensi-potensi untuk mengatasi masalah. Progresivisme juga menaruh kepercayaan terhadap kebebasan manusia dalam menentukan hidupnya, serta lingkungan hidup yang dapat mempengaruhi kepribadiannnya. Beberapa hal yang terkandung dalam Aliran Progresivisme ini secara mendalam dipikirkan untuk kemudian memunculkan sebuah paradigma pendidikan yang baru, karena sedang menjadi primadona paradigma pendidikan dewasa ini, yang tidak lain adalah pendidikan karakter.

Pada ranah Islam kita mengenal istilah filsafat akhlak. Filsafat akhlak ini sangat dekat dengan tasawuf, karena tasawuf sebagai akar dari filsafat akhlak yang memberikan pengaruh terhadap pembentukan karakter. Pemikir akhlak salah satunya adalah al-Gazāli dengan karyanya Ihyā' 'Ulüm al-Din. Pengalaman spiritual para 
sufi yang membawa implikasi kesucian akhlak merupakan pokok pemikiran akhlak. Dari peneladanan terhadap para sufi tersebut, akan melahirkan sebuah kebiasaan (habit) yang senantiasa berbuat kebajikan. Pendidikan akhlak yang dipraktekkan secara terus menerus akan membentuk sebuah karakter seseorang. Pendidikan akhlak pada konteks ini menginspirasi terbentuknya pendidikan karakter dan penerapannya.

Sebagai dasar acuan dalam merumuskan konsep pendidikan karakter dalam Islam ialah Q.S. a;-Rūm ayat 30.

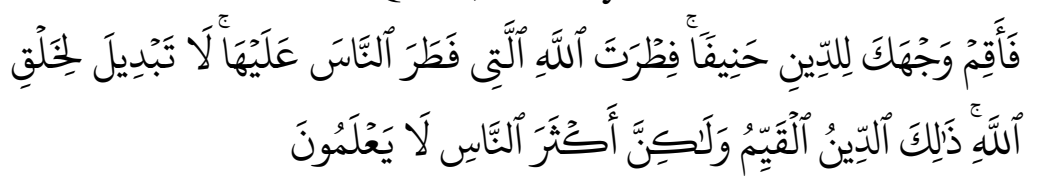

"Maka hadapkanlah wajahmu dengan lurus kepada agama Allah; (tetaplah atas) fitrah Allah yang telah menciptakan manusia menurut fitrah itu. Tidak ada perubahan pada fitrah Allah. (Itulah) agama yang lurus; tetapi kebanyakan manusia tidak mengetahui”.

Dari ayat di atas dapat ditarik benang merah bahwa bawaan dasar (fitrah) manusia dan proses pembentukan karakternya dapat dikelompokkan menjadi empat aliran yaitu: 1) fatalis-pasif,2) netral-pasif, 3) positif-aktif dan, 4) dualis-aktif.

1. Aliran yang berpandangan fatalis-pasif, mempercayai bahwa setiap individu karakternya baik atau jahat melalui ketetapan Allah. Faktor-faktor eksternal, termasuk paradigma pendidikan karakter tidak begitu berpengaruh karena setiap individu terikat dengan ketetapan yang telah ditentukan sebelumnya. Karakter positif atau negatif seseorang telah ditentukan lebih dahulu sebelum dia lahir ke dunia yang dikenal dengan Ilmu Azali Allah.

2. Pandangan netral-pasif, yakni anak lahir dalam keadaan suci, utuh dan sempurna, suatu keadaan kosong. Sama halnya dengan teori tabula rasa yang dikemukakan John Lock bahwa manusia lahir seperti kertas putih tanpa ada sesuatu goresan apa pun. Manusia berpotensi berkarakter baik dan tidak baik itu karena mendapat pengaruh dari luar terutama orang tua. Pengaruh baik dan buruk tersebut akan terus mengiringi kehidupan setiap insan dan karakter yang terbentuk tergantung mana yang dominan memberi pengaruh. Jika pengaruh baik lebih dominan, maka seseorang akan berkarakter baik, begitu 
pula sebaliknya. Pandangan ini mengambil argumen dari Q.S. al-Nahl/16: 78 .

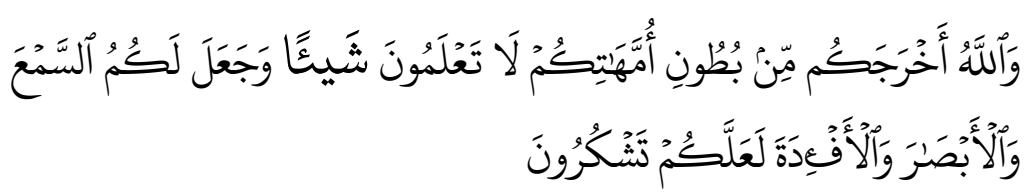

"Dan Allah mengeluarkan kamu dari perut ibumu dalam Keadaan tidak mengetahui sesuatu apapun, dan Dia memberi kamu pendengaran, penglihatan dan hati, agar kamu bersyukur."

3. Aliran positif-aktif, yakni bawaan dasar atau sifat manusia sejak lahir adalah berkarakter baik, kuat dan aktif, sedangkan lingkunganlah yang membelenggu manusia sehingga ia menjauh dari sifat bawaannya.

4. Aliran dualis-aktif, yakni manusia memiliki dua sifat ganda yang sama kuatnya. Sifat baik dan buruk. Tergantung kedekatan manusia terhadap lingkungan yang baik atau buruk. Jika ia dekat dengan teman yang berkarakter baik, maka seseorang tersebut akan mengambil sifat baiknya, dan sebaliknya. Penanaman kebiasaan positif amat penting untuk diupayakan sejak kecil agar karakter atau sifat baik lebih kuat.

Dasar pembentukan karakter adalah nilai baik (disimbolkan sebagai nilai malaikat) atau buruk (disimbolkan sebagai nilai setan). Karakter manusia merupakan hasil tarik-menarik antara nilai baik dalam bentuk energi positif dan nilai buruk dalam bentuk energi negatif. Energi positif itu berupa nilai-nilai etis religius yang bersumber dari keyakinan kepada Tuhan, sedangkan energi negatif itu berupa nilai-nilai yang amoral yang bersumber dari tăgüt (setan).

\section{Penilaian yang Objektif dan Transparan}

Penilaian ditinjau dari sudut bahasa, diartikan sebagai proses menentukan nilai suatu objek. Untuk dapat menentukan suatu nilai atau harga suatu objek diperlukan adanya ukuran atau kriteria. Misalnya untuk dapat mengatakan baik, sedang, kurang, diperlukan adanya ukuran yang jelas bagaimana baik, yang sedang, dan kurang. Ukuran itulah yang dinamakan kriteria. ${ }^{9}$

${ }^{9}$ Depdiknas, Penilaian Hasil Belajar, (Jakarta: Direktorat Tenaga Kependidikan Direktorat Jenderal Peningkatan Mutu Pendidik dan Tenaga Kependidikan, 2008), hlm.5. 
Penilaian adalah proses untuk mengetahui apakah proses dan hasil dari suatu program kegiatan telah sesuai dengan tujuan atau kriteria yang telah ditetapkan. Penilaian dapat dilakukan secara tepat, jika tersedia data yang berkaitan dengan objek penilaian. ${ }^{10}$

Dari kedua pengertian tersebut, dapat dikatakan bahwa ciri penilaian adalah adanya objek atau program yang dinilai dan sebagai dasar untuk membandingkan antara apa yang dicapai dengan kriteria yang harus dicapai. Perbandingan bisa bersifat mutlak, bisa relatif. Perbandingan bersifat mutlak artinya hasil perbandingan tersebut menggambarkan posisi objek yang dinilai ditinjau dari kriteria yang berlaku. Sedangkan perbandingan yang bersifat relatif artinya hasil perbandingan lebih menggambarkan posisi suatu objek yang dinilai terhadap objek lainnya dengan bersumber pada kriteria yang sama. Dengan demikian, inti penilaian adalah proses menentukan nilai suatu objek tertentu berdasarkan kriteria tertentu.

Pada kurikulum Kurikulum Tingkat Satuan Pendidikan (KTSP)Tahun 2006 sebagaimana terlampir dalam Peraturan Menteri Pendidikan Nasional Nomor 20 Tahun 2007 tanggal 11 Juni 2007 tentang Standar Penilaian Pendidikan, bahwa penilaian hasil belajar peserta didik khususnya pada jenjang pendidikan dasar dan menengah didasarkan pada prinsip- prinsip sebagai berikut:1) sahih, berarti penilaian didasarkan pada data yang mencerminkan kemampuan yang diukur; 2) objektif, berarti penilaian didasarkan pada prosedur dan kriteria yang jelas, tidak dipengaruhi subjektivitas penilai; 3) adil, berarti penilaian tidak menguntungkan atau merugikan peserta didik karena berkebutuhan khusus serta perbedaan latar belakang agama, suku, budaya, adat istiadat, status sosial ekonomi, dan gender; 4) terpadu, berarti penilaian oleh pendidik merupakan salah satu komponen yang tak terpisahkan dari kegiatan pembelajaran; 5) terbuka, berarti prosedur penilaian, kriteria penilaian, dan dasar pengambilan keputusan dapat diketahui oleh pihak yang berkepentingan; 6) menyeluruh dan berkesinambungan, berarti penilaian oleh pendidik mencakup semua aspek kompetensi dengan menggunakan berbagai teknik penilaian yang sesuai, untuk memantau perkembangan kemampuan peserta didik; 7) sistematis, berarti penilaian dilakukan secara berencana dan bertahap dengan

${ }^{10}$ Suwandi Sarwiji, Model-Model Assesmen dalam Pembelajaran, (Surakarta: Yuma Pustaka, 2011), hlm.9. 
mengikuti langkah-langkah baku; 8) beracuan kriteria, berarti penilaian didasarkan pada ukuran pencapaian kompetensi yang ditetapkan; 9) akuntabel, berarti penilaian dapat dipertanggungjawabkan, baik dari segi teknik, prosedur, maupun hasilnya.

Sementara Standar Penilaian Pendidikan dalam kurikulum 2013 sebagaimana disebutkan dalam Permendikbud No. 66 Tahun 2013 bahwa Standar Penilaian Pendidikan adalah kriteria mengenai mekanisme, prosedur, dan instrumen penilaian hasil belajar peserta didik. Adapun prinsip penilaian tersebut adalah: 1) objektif, berarti penilaian berbasis pada standar dan tidak dipengaruhi faktor subjektivitas penilai; 2) terpadu, berarti penilaian oleh pendidik dilakukan secara terencana,menyatu dengan kegiatan pembelajaran, dan berkesinambungan; 3) ekonomis, berarti penilaian yang efisien dan efektif dalam perencanaan, pelaksanaan, dan pelaporannya; 4) transparan, berarti prosedur penilaian, kriteria penilaian, dan dasar pengambilan keputusan dapat diakses oleh semua pihak; 5) akuntabel, berarti penilaian dapat dipertanggungjawabkan kepada pihak internal maupun eksternal untuk aspek teknik, prosedur, dan hasilnya; 6) edukatif, berarti mendidik dan memotivasi peserta didik dan pendidik.

Prinsip-prinsip penilaian di atas, yang akan dibahas lebih lanjut dalam tulisan ini adalah bagaimana penilaian yang objektif dan transparan? Penilaian yang objektif adalah penilaian tidak memihak, tidak menguntungkan atau merugikan salah satu pihak, serta tidak memandang perbedaan latar belakang agama, suku, budaya, adat istiadat, status sosial ekonomi, dan gender. Sementara penilaian yang transparan adalah penilaian yang bersifat terbuka dan pihak yang terkait harus tahu bagaimana pelaksanaan penilaian tersebut, dari aspek apa saja nilai tersebut didapat, dasar pengambilan keputusan, dan bagaimana pengolahan nilai tersebut sampai hasil akhirnya tertera, dan dapat diterima.

\section{Pendidikan Karakter Berbasis Nilai}

Nilai adalah prinsip-prinsip sosial, tujuan-tujuan, atau standar yang dipakai atau diterima oleh individu, kelas, masyarakat, dan lain-lain. Mengingat nilai erat kaitannya dengan kebaikan, kendati keduanya memang tidak sama, karena sering kali sesuatu yang baik tidak selalu bernilai tinggi bagi seseorang atau sebaliknya.

Dilihat dari terminologinya, nilai berbeda dengan etika. Nilai adalah suatu pengertian atau pensifatan yang digunakan untuk 
memberikan penghargaan terhadap barang atau benda. Manusia menganggap sesuatu bernilai, karena ia merasa memerlukan atau menghargainya. Dengan akal dan budinya manusia menilai dunia dan alam sekitarnya untuk memperoleh kepuasan diri baik dalam arti memperoleh apa yang diperlukannya, apa yang menguntungkannya, atau apa yang menimbulkan kepuasan batinnya. Nilai sebagai hal abstrak, yang harganya mensifati dan disifatkan pada sesuatu hal yang ciri-cirinya dapat dilihat dari tingkah laku, memiliki kaitan dengan istilah fakta, tindakan, norma, moral, citacita, keyakinan, dan kebutuhan.

Dalam realitas kehidupan individu dan sosial, nilai berkait erat dengan istilah-istilah lain. Nilai berkait erat dengan tindakan, norma, moral, aspek-aspek psikologis, dan etika. Kaitan antara nilai dengan istilah-istilah tersebut lebih mencerminkan sebagai proses yang menyatu daripada sebagai istilah yang terpisahkan. Misalnya, antara nilai dan tindakan, bahwa nilai berlaku sebagai tujuan yang melekat dalam tindakan.

Berdasarkan uraian tersebut, dapat disimpulkan bahwa pengertian dan makna nilai adalah suatu bobot/kualitas perbuatan kebaikan yang dalam berbagai hal dianggap sebagai sesuatu yang berharga, berguna dan memiliki manfaat.

Secara garis besar nilai dibagi dalam dua kelompok yaitu nilainilai nurani (values of being) dan nilai-nilai memberi (values of giving). Nilai nurani adalah sesuatu yang ada dalam diri manusia kemudian berkembang menjadi perilaku serta cara kita memperlakukan orang lain. Yang termasuk dalam nilai nurani adalah kejujuran, keberanian, cinta damai, keandalan diri, potensi, disiplin, tahu batas, kemurnian, dan kesesuaian. Sedangkan nilai memberi adalah nilai yang perlu dipraktikkan atau diberikan yang kemudian akan diterima sebanyak yang diberikan. Yang termasuk pada kelompok nilai ini adalah setia, dapat dipercaya, hormat, cinta, kasih, peka, tidak egois, baik hati, ramah, adil, dan murah hati. ${ }^{11}$

Secara epistemologi, nilai membicarakan tiga hal, yaitu objek nilai, cara memperoleh nilai, dan ukuran kebenaran nilai. Objek nilai dapat diidentifikasi dari istilah rujukan yang terdapat dalam definisi nilai. Rujukan ini menentukan pilihan seseorang dalam menetapkan tujuan hidup beserta tindakan-tindakan yang diarahkan

${ }^{11}$ Linda N. Eyre, Richard, Teaching Your Children Values, (New York: Simon sand Chuster, 1995), hlm. 28-29. 
pada pencapaian tujuan itu. Objek nilai tadi tidak memiliki arti apaapa kalau manusia tidak menilai objek tersebut. Artinya, nilai ada kalau manusia melakukan penilaian. Bagaimana kita tahu bahwa ia memiliki nilai dan melakukan penilaian? Hal itu dapat dilihat dari tingkah lakunya yang diprediksi tertuju pada pencapaian nilai tertentu. Karena itu, selain objek nilai yang disebutkan tadi, tingkah laku merupakan objek nilai yang paling aktual. Tingkah laku sebagai objek nilai dapat berupa perilaku religius, karakter berpikir filosofis, sikap ilmiah, perilaku etis, dan perilaku estetis.

Contoh nilai dalam ekonomi, nilai suatu barang pada dasarnya hasil akhir dari pertimbangan logis, etis, dan estetis. Suatu barang dapat bernilai tinggi apabila nilai logis menyatakan benar-khususnya menurut ilmu ekonomi, nilai etis menyatakan hal itu baik untuk kesehatan atau kesejahteraan manusia, dan nilai estetis menyatakan hal itu bermutu dari segi keindahannya. Demikian pula, nilai tertinggi dalam agama adalah nilai yang memenuhi persyaratan logis, etis, dan estetis. Sebagai contoh, nilai keimanan yang dicapai melalui amaliah salat akan memiliki nilai yang tinggi, jika salat dilakukan atas dasar pengetahuan kita tentang nilai kebenaran dalam melakukan tata cara salat, nilai kebaikan salat yang direfleksikan melalui hubungan antar manusia, dan nilai kebersihan atau kesucian ketika kita melakukan salat. Sedangkan pemberian nilai terhadap kegiatan dan kemajuan belajar mahasiswa dilakukan penilaian secara berkala yang dapat berupa ujian, pelaksanaan tugas, dan pengamatan oleh dosen. Tentunya mahasiswa mendapatkan nilai dihargai oleh dosen sesuai dengan pekerjaannya dalam menjawab soal ujian maupun dalam menyelesaikan tugas yang diberikan. Mahasiswa yang mendapatkan nilai tinggi tentunya mampu memberikan jawaban sesuai yang diharapkan pada soal ujian. Begitu pula dalam penyelesaian tugas, dosen akan memberikan nilai yang tinggi apabila tugas yang dikerjakan mahasiswa sesuai dengan indikator tugas yang diharapkan

Uraian di atas menegaskan bahwa kategori nilai yang paling elementer terletak pada sifatnya yang logis, etis, dan estetis. Nilai dasar ini berada pada wilayah nilai tersendiri dan tergantung dari objek yang dinilai, cara memberi nilai dan ukuran kebenaran dalam memberi nilai. Semua itu tidak lepas dari internalisasi pendidikan karakter. 


\section{E. Internalisasi Pendidikan Karakter Berbasis Nilai pada Mata Kuliah Statistika Pendidikan melalui Sistem Penilaian yang Objektif dan Transparan}

Saat ini, sebagian mahasiswa melihat globalisasi dari sisi lahirnya saja, dengan produk teknologi yang memanjakan. Bahkan hampir semua kebutuhan dan keinginannya dengan mudah bisa dipenuhi. Kebanyakan mahasiswa menyukai hal-hal yang instan, mereka tidak mau bersusah payah, berproses dari nol, serta melalui berbagai macam rintangan dan halangan silih berganti, jatuh bangun dan sebagainya. Mentalitas mahasiswa seperti ini akan menghilangkan aspek kreativitas, kepeloporan dan ketokohan pada diri mereka.

Mengamati kecenderungan mahasiswa dalam mengikuti perkuliahan, hanya mementingkan kelulusan dan kurang serius mengikuti penjelasan materi yang diberikan, meskipun tetap hadir mengikuti kuliah. Ketika memasuki tahap tugas, mahasiswa mulai kehilangan gairah. Fenomena lain yang terjadi pada saat perkuliahan yaitu mahasiswa cenderung mencari materi-materi atau tugas-tugas yang telah diberikan pada semester lalu untuk angkatan sebelumnya, sehingga apabila materi yang diberikan sama, maka tugastugas diselesaikan dengan cara menjiplak tugas yang telah dikerjakan oleh kakak tingkat sebelumnya. Hal ini membuat mahasiswa menjadi malas dan cenderung mengambil jalan pintas. Kebiasaan jalan pintas yang tidak menumbuhkan nilai kejujuran, kedisiplinan dan tanggung jawab harus dihilangkan dari diri mahasiswa.

Mata kuliah Statistika Pendidikan merupakan salah satu mata kuliah yang diajarkan pada Prodi Manajemen Pendidikan Islam (MPI) Fakultas Tarbiyah dan Ilmu Keguruan IAIN Sultan Amai Gorontalo. Berdasarkan kurikulum yang ada di Prodi ini, pengajaran mata kuliah ini diberikan pada semester keempat sebanyak tiga satuan kredit semester (SKS) dalam seminggu. Tujuan diajarkannya mata kuliah ini, adalah agar mahasiswa Prodi MPI: 1) memahami dan mengerti beberapa istilah statistika dan manfaatnya, 2) mampu menggunakan statistika sebagai alat bantu dalam penyusunan laporan penelitian di bidang pendidikan, 3) mampu menggunakan rumus-rumus dan teknik-teknik analisis statistika dalam penyusunan laporan penelitian di bidang pendidikan, 4) dapat memiliki sikap teliti dan cermat dalam menerima dan mengemukakan sesuatu. Intinya dengan belajar Statistika Pendidikan, diharapkan mahasiswa memahami konsep dan prosedur statistika dan mampu menerapkannya untuk menganalisis permasalahan pendidikan. 
Mengingat hampir semua bidang tidak terlepas dengan penggunaan angka, data dan fakta.

Uraian di atas, menunjukkan bahwa pembelajaran Statistika Pendidikan di Prodi MPI Fakultas Tarbiyah dan Ilmu Keguruan IAIN Sultan Amai Gorontalo tidak dimaksudkan untuk mencetak calon-calon sarjana dalam ilmu statistika, melainkan untuk membekali mahasiswa dengan pengetahuan statistika yang dipandang perlu dan relevan untuk dimiliki oleh seorang peneliti (research worker) di bidang pendidikan. Hal ini menunjukkan bahwa mata kuliah Statistika Pendidikan sangat dibutuhkan, terutama oleh pendidik dan administrator di bidang kependidikan.

Statistika berfungsi sebagai sarana mengembangkan cara berpikir secara logis. Secara ilmiah untuk merencanakan (forecasting) penyelidikan, menyimpulkan dan membuat keputusan yang diteliti dan meyakinkan. ${ }^{12}$ Baik disadari atau tidak, statistika pendidikan merupakan bagian esensial dari latihan profesional dan menjadi landasan dari kegiatan-kegiatan penelitian yang dilakukan oleh seorang pendidik dan seorang administrator di bidang kependidikan. Mata kuliah ini juga menjadi bagian yang tak terpisahkan dari seluruh materi perkuliahan yang lain yaitu mata kuliah Evaluasi Pembelajaran dan Metode Penelitian dan sangat mendukung mahasiswa dalam menyiapkan penulisan skripsi.

Berdasarkan pengalaman penulis selama mengampu mata kuliah Statistika Pendidikan, baik di Prodi MPI maupun di Prodi lain yang ada di Fakultas Tarbiyah dan Ilmu Keguruan IAIN Sultan Amai Gorontalo, menunjukkan banyak mahasiswa yang menganggap mata kuliah ini sulit, rumit dan menakutkan oleh sebagian mahasiswa yang tidak mengerti asal mulanya. Hal ini didasarkan karena materinya lebih banyak yang bersifat menghitung. Padahal belajar statistika itu sangat mudah apalagi mempunyai dasar Matematika yang baik, bahkan mengetahui hitungan sedikitpun akan merasa mudah dan tidak mengalami kesukaran asalkan tekun dan rutin mengerjakan contoh-contoh persoalan statistika.

Berdasarkan pantauan selama ini, mahasiswa yang memiliki kemampuan kuantitatif yang rendah, maka mata kuliah ini menjadi

\footnotetext{
${ }^{12}$ Sudijono Anas, Pengantar Statistik Pendidikan, (Jakarta: Raja Grafindo Persada, 2010), hlm.1.
} 
mata kuliah yang tidak menarik. Hal ini tampak erat sekali hubungannya dengan bekal kemampuan dasar yang dimiliki oleh mahasiswa dalam mata pelajaran Matematika pada saat mereka menduduki jenjang pendidikan tingkat SLTA. Penulis mengamati bahwa sebagian besar mahasiswa di Prodi MPI berasal dari sekolah atau madrasah di lingkungan Kementerian Agama, dirasakan sebagai salah satu "momok". Sehingga hanya dengan penuh kesabaran dan bahasa yang sesederhana mungkin,materi pengajaran Statistika Pendidikan dapat diserap dan dipahami oleh mahasiswa. Tidak ada alternatif lain kecuali agar mereka tekun dan rajin mempelajari Statistika Pendidikan.

Rendahnya hasil belajar mahasiswa terlihat dari nilai yang dicapainya saat yang mengikuti mata kuliah ini. Berdasarkan hasil evaluasi Ujian Tengah Semester tahun akademik 2013/2014 ditemukan bahwa nilai yang diperoleh mahasiswa untuk mata kuliah ini belum optimal, artinya masih banyak jumlah mahasiswa yang mendapatkan nilai di bawah standar. Hasil evaluasi mahasiswa semester IV Prodi Manajemen Pendidikan Islam Fakultas Tarbiyah dan Ilmu Keguruan IAIN Sultan Amai Gorontalo tahun akademik 2013/2014 menunjukkan bahwa nilai mahasiswa yang di atas B hanya mencapai $29 \%$, sedangkan sisanya $71 \%$ nilai mahasiswa dengan nilai B ke bawah. Hal ini disebabkan karena rata-rata mahasiswa kurang mampu menjawab dengan tepat terhadap soal yang diberikan pada kegiatan evaluasi pembelajaran, khususnya soal-soal yang sifatnya aplikatif. Akibatnya nilai yang dicapai mahasiswa juga kurang memuaskan.

Berdasarkan hasil analisis terhadap pola jawaban mahasiswa terlihat bahwa sebagian besar mahasiswa mampu menjawab soal yang sifatnya teoretis. Namun untuk soal yang sifatnya aplikatif, sebagian besar mahasiswa kurang mampu menjawab dengan benar. Hal ini menunjukkan bahwa kemampuan mahasiswa masih dalam tataran teoretis belaka sedangkan kemampuan mahasiswa untuk mengaplikasikan konsep teori yang diterimanya masih kurang.

Guna mengatasi permasalahan tersebut, paradigma pendidikan yang dominan untuk membentuk karakter nilai kejujuran, kedisiplinan dan tanggung jawab dalam pembelajaran Statistika Pendidikan adalah melalui penerapan sistem penilaian yang objektif dan transparan. 


\section{Internalisasi Melalui Penilaian yang Objektif}

Penilaian yang bersifat objektif tidak memandang dan membeda-bedakan latar belakang mahasiswa, namun melihat kompetensi yang dihasilkan oleh mahasiswa tersebut, bukan atas dasar siapa dirinya. Penilaian harus dilaksanakan secara objektif dan tidak dipengaruhi oleh subyektivitas penilai. Contoh: Dosen memberi nilai 3,50 untuk materi yang diujikan pada si A yang merupakan tetangga dari dosen tersebut, namun si B, yang kemampuannya lebih baik, mendapatkan nilai hanya 3,0. Ini adalah penilaian yang bersifat subyektif dan tidak disarankan. Pemberian nilai haruslah berdasarkan kemampuan mahasiswa secara objektif.

Untuk menerapkan sistem penilaian objektif yang mampu menginternalisasi karakter sikap kejujuran, kedisiplinan dan tanggung jawab pada mata kuliah Statistika Pendidikan. Penulis mengupayakan di setiap pertemuan dengan memberi tugas kepada mahasiswa sebagai latihan di rumah. Untuk menghindari kebiasaan mahasiswa meniru tugas atau pekerjaan kakak tingkat sebelumnya, penulis lakukan dengan pengarsipan tugas-tugas yang pernah diberikan. Kepada mahasiswa untuk angkatan yang berbeda selalu diberi tugas-tugas yang berbeda sehingga mahasiswa tidak menggantungkan diri pada tugas dan pekerjaan yang telah dilakukan sebelumnya. Tugas yang dikerjakan mahasiswa selalu dikumpulkan tepat waktu sesuai kesepakatan yang telah dibuat, dan diberi nilai sesuai hasil pekerjaannya kemudian dikembalikan kepada mahasiswa yang bersangkutan agar mahasiswa mengetahui letak kesalahan tugas yang dikerjakan guna untuk perbaikan, dan dengan nilai yang mereka dapatkan memotivasinya untuk belajar di rumah dan selalu mengerjakan tugas-tugas yang diberikan. Bagi mahasiswa yang pekerjaannya sama, akan dikembalikan dan tidak diberi nilai, hal ini dilakukan untuk memupuk kejujuran, kedisiplinan dan tanggung jawab pada diri mahasiswa.

Dampak dari semua ini adalah suasana belajar semakin kondusif, mahasiswa merasa senang dan tidak jenuh mengikuti perkuliahan serta sudah menganggap mata kuliah Statistika Pendidikan penting untuk dipelajari karena sudah dipahami tujuan dan manfaatnya dengan baik. Dengan sistem penilaian yang objektif diterapkan penulis selama ini mahasiswa tidak sekedar menghafal teori ataupun konsep-konsep semata, tetapi 
ternyata mereka memahami lebih holistik dan kontekstual dari materi yang mereka dapatkan mulai dari memahami pengertian dan macam statistika pendidikan, memahami kedudukan dan kegunaan statistika di dunia pendidikan, memahami data dan macam data statistika pendidikan, menyusun distribusi frekuensi data tunggal dan kelompok, menghitung ukuran tendensi sentral data statistika pendidikan, mengukur sebaran data statistika pendidikan, menghitung indek perbedaan antar variabel data statistika pendidikan, dan menghitung harga indek hubungan antar variabel data statistika pendidikan. Mahasiswa tidak sekadar memenuhi frekuensi perkuliahan tetapi lebih bergairah untuk belajar.

Dengan latihan-latihan dan tugas-tugas yang diberikan di setiap pertemuan, mahasiswa sudah terbiasa dalam memecahkan masalah-masalah terkait dengan materi Statistika Pendidikan yang diajarkan. Pemberian tugas yang berbeda dengan sebelumnya, sebagaimana yang penulis rancang dan langsung diberi nilai sesuai hasil pekerjaannya, membuat mahasiswa lebih aktif untuk mengerjakan tugas-tugas yang diberikan dan tidak meniru (menjiplak) tugas sebelumnya atau pekerjaan temannya. Hal ini telah memupuk kejujuran dan kedisiplinan pada diri mahasiswa untuk bertanggungjawab pada dirinya sendiri. Cara demikian juga mendorong mahasiswa mengerjakan dengan tenaga dan pikiran masing-masing yang pada gilirannya akan mengkikis kebiasaan meniru (menjiplak) sehingga mahasiswa akan memiliki kemampuan yang lebih tinggi dalam memecahkan masalah yang dihadapi.

2. Internalisasi Melalui Penilaian yang Transparan

Penilaian harus bersifat transparan dan pihak yang terkait harus tahu bagaimana pelaksanaan penilaian tersebut, dari aspek apa saja nilai tersebut didapat, dasar pengambilan keputusan, dan bagaimana pengolahan nilai tersebut sampai hasil akhirnya tertera, dan dapat diterima.

Untuk menerapkan sistem penilaian yang transparan yang mampu menginternalisasi nilai karakter pada mata kuliah Statistika Pendidikan, upaya yang penulis lakukan pada awal perkuliahan, menerangkan tentang kesepakatan pemberian nilai dengan bobot masing-masing aspek, misalnya partisipasi kehadiran diberi bobot $20 \%$, tugas individu dan kelompok masing- 
masing 20\%, Ujian Tengah Semester 25\%, Ujian Akhir Semester $35 \%$. Dalam memberikan tugas baik tugas mandiri maupun tugas kelompok dikumpulkan sesuai dengan waktu yang ditentukan, memberikan UTS dan UAS sesuai aturan yang berlaku, mahasiswa akan diizinkan mengikuti ujian akhir setelah mengikuti minimal $75 \%$ perkuliahan. Sehingga di sini terjadi keterbukaan penilaian antara dosen dan mahasiswa.

Begitupun dalam hal penilaian baik tugas, UTS maupun UAS dilaksanakan secara transparan sesuai dengan aturan yang berlaku. Sistem penilaian secara transparan dilakukan dengan mengoreksi dan mengembalikan tugas kuliah, hasil UTS maupun hasil UAS kepada mahasiswa. Mahasiswa juga diberi kesempatan melakukan klarifikasi atau komplain terhadap nilainya dalam jangka waktu tertentu atau sebelum nilai dimasukkan di Bagian Akademik, namun jika ada komplain disampaikan di luar waktu yang ditentukan maka tidak akan dilayani. Untuk mencapai sesuatu yang baik tentunya baik dosen maupun mahasiswa harus disiplin dan bekerja sama mencapai kedisiplinan tersebut. Sistem penilaian yang transparan juga diterapkan oleh penulis dalam mengevaluasi diri di akhir perkuliahan. Evaluasi ini dilakukan dengan meminta tanggapan dari mahasiswa sesuai aspek-aspek yang dievaluasi yakni metode pembelajaran, media pembelajaran, materi pembelajaran dan teknik penilaian yang digunakan dalam bentuk check list untuk pencapaian tujuan, proses dan hasil belajar mahasiswa yang lebih baik lagi.

\section{F. Penutup}

Keberhasilan internalisasi pendidikan karakter berbasis nilai pada diri mahasiswa akan terwujud, apabila kalangan akademisi terutama dosen Prodi MPI mampu menyumbangkan pikiranpikiran orisinal aplikatif dalam pengembangan model internalisasi pendidikan karakter berbasis nilai pada setiap proses perkuliahan sesuai mata kuliah yang diajarkan. Dosen sebagai motivator dan evaluator bertanggung jawab menyuntikkan virus karakter kepada diri mahasiswa secara bertahap, sistematis, disiplin, dan kreatif. Selain itu sebagai dosen harus mampu meningkatkan hasil belajar mahasiswa dengan memompa semangat belajarnya melalui penerapan sistem penilaian yang objektif dan transparan, sehingga mereka berani menghadapi tantangan, berpikir solutif, bergerak optimis 
dengan ekspektasi dan keyakinan diri yang tinggi, sehingga ke depan mahasiswa lebih berkualitas dan kompetitif.

\section{Kepustakaan}

Aqib, Zainal \& Sujak, Panduan dan Aplikasi Pendidikan Karakter untuk SD/MI, SMP/MTs,SMA/MA, SMK/MAK, (Bandung: Yrama Widya, 2012).

Asmani, Jamal Ma'mur, Buku Panduan Internalisasi Pendidikan Karakter di Sekolah, (Yogyakarta: DIVA Press, 2012).

Departemen Pendidikan Nasional, Penilaian Hasil Belajar, (Jakarta: Direktorat Tenaga Kependidikan Direktorat Jenderal Peningkatan Mutu Pendidik dan Tenaga Kependidikan, 2008).

Doni, Koesoemo Albertus, Pendidikan Karakter: Strategi Mendidik Anak di Zaman Global, (Jakarta: Grasindo, 2010).

Ewing, A.C., Persoalan-Persoalan Mendasar Filsafat, (Yogyakarta: Pustaka Pelajar, 2008).

Kementerian Pendidikan Nasional, Pengembangan Pendidikan Budaya dan Karakter Bangsa, (Jakarta: Badan Penelitian dan Pengembangan Pusat Kurikulum dan Perbukuan, 2010).

Kementerian Agama Republik Indonesia, Al-Quran dan Terjemahnya, (Bandung: Media Fitrah Rabbani, 2012).

Khan, Yahya, Pendidikan Karakter Berbasis Potensi Diri: Mendongkrak Kualitas Pendidikan, (Yogyakarta: Pelangi Publishing, 2010).

Rahman, Putri, Pendidikan Karakter. (http://calongurukimia.blogspot.com/2012/06/ pendidikan-karakter.html, diakses: 15 Mei 2014.

Samani, Muchlas \& Hariyanto, Pendidikan Karakter, (Bandung: Remaja Rosdakarya, 2011).

Suwandi, Sarwiji, Model-Model Assesmen dalam Pembelajaran, (Surakarta: Yuma Pustaka, 2011).

Zaenul, Fitri Agus, Pendidikan Karakter Berbasis Nilai \& Etika di Sekolah, (Yogyakarta: Ar- Ruzz Media, 2012).

Zubaidi, Desain Pendidikan Karakter, (Jakarta: Prenada Media Group, 2011). 
